\title{
Effect of plant growth-promoting Streptomyces sp. on growth promotion and grain yield in chickpea (Cicer arietinum $\mathrm{L}$ )
}

\author{
S. Gopalakrishnan • V. Srinivas • G. Alekhya • \\ B. Prakash
}

Received: 26 September 2014 / Accepted: 3 February 2015/Published online: 13 February 2015

(c) The Author(s) 2015. This article is published with open access at Springerlink.com

\begin{abstract}
The physiological and molecular responses of six strains of Streptomyces sp. (CAI-13, CAI-85, CAI-93, CAI-140, CAI-155 and KAI-180), with their proven potential for plant growth-promotion (PGP) in rice were studied to understand the mechanisms causing the beneficial effects. In this investigation, those six strains were evaluated for their PGP capabilities in chickpea in the 2012-13 and 2013-14 post-rainy seasons. All of the Streptomyces sp. strains exhibited enhanced nodule number, nodule weight, root weight and shoot weight at 30 days after sowing (DAS) and pod number, pod weight, leaf area, leaf weight and stem weight at 60 DAS in both seasons over the un-inoculated control. At chickpea crop maturity, the Streptomyces strains had enhanced stover yield, grain yield, total dry matter, pod weight, seed number and seed weight in both seasons over the uninoculated control. In the rhizosphere, at crop maturity, the Streptomyces strains also significantly enhanced soil biological and mineral nutrient traits including microbial biomass carbon, dehydrogenase activity, total nitrogen, available phosphorous and organic carbon in both seasons over the un-inoculated control. Of the six strains of Streptomyces sp., CAI-85, CAI-93 and KAI-180 were found superior to CAI-155, CAI-140 and CAI-13, in terms of their effects on root and shoot development, nodule formation and crop productivity. Scanning electron microscopy micrographs had revealed the success in colonization of the chickpea roots by all six strains. This investigation further confirms the broad-spectrum of PGP activities by the selected Streptomyces sp.
\end{abstract}

S. Gopalakrishnan $(\bowtie) \cdot$ V. Srinivas · G. Alekhya · B. Prakash International Crops Research Institute for the Semi-Arid Tropics (ICRISAT), Patancheru 502 324, Telangana, India

e-mail: s.gopalakrishnan@cgiar.org
Keywords Plant growth promotion - Streptomyces sp. . Field demonstration - Scanning electron microscopy

\section{Introduction}

Intensive farming practices, that warrant high yield and quality, require extensive use of chemical fertilizers and pesticides, which are costly and create environmental problems. Hence, there has been a resurgence of interest in environmental friendly, sustainable and eco-friendly agricultural practices (Esitken et al. 2002). Application of plant growth-promoting (PGP) bacteria is gaining importance in sustainable agricultural systems because of their low production costs, consumption of less non-renewable resources and eco-friendliness in nature. The mechanisms involved in plant growth promotion by PGP bacteria include secretion of PGP hormones, chelation of iron, nitrogen fixation, solubilization of phosphorus and inhibition of plant pathogens (Tokala et al. 2002; Soares et al. 2006; Cheng et al. 2007; Hao et al. 2011; Panhwar et al. 2012). Application of PGP bacteria on the rhizosphere had been reported to enhance root and shoot growth, nitrogen fixation and solubilization of minerals (Shaukat et al. 2006; Richardson et al. 2009). PGP bacteria such as Rhizobium, Pseudomonas, Bacillus and Streptomyces were reported to help the plants not only by mobilizing the nutrients but also by controlling plant pathogens (Postma et al. 2003; Perner et al. 2006; Gopalakrishnan et al. 2011a, b).

Streptomyces, a Gram positive bacterium with high $\mathrm{G}+$ $\mathrm{C}$ content, is the largest genus of actinomycetes having more than 500 species found predominantly in soil and decaying vegetation. They are known for PGP, breakdown of carbohydrates such as chitin and cellulose and 
degradation of soils contaminated with pesticides and heavy metals thereby playing a greater role in the process of phytoremediation (Glick 2010). PGP potential of Streptomyces was reported on cereals such as wheat (Sadeghi et al. 2012) and rice (Gopalakrishnan et al. 2013, 2014), legumes such as beans (Nassar et al. 2003) and peas (Tokala et al. 2002) and vegetables such as tomato (ElTarabily 2008). Streptomyces promote plant growth by producing indole-3-acetic acid (IAA) (Aldesuquy et al. 1998) or siderophores (Tokala et al. 2002). Besides, Streptomyces has been extensively used for biocontrol of soil-borne fungal pathogens (Mahadevan and Crawford 1997; Trejo-Estrada et al. 1998; Macagnan et al. 2008; Gopalakrishnan et al. 2011b).

Chickpea (Cicer arietinum $\mathrm{L}$ ) is the third most important pulse crop after beans (Phaseolus vulgaris) and peas (Pisum sativum) on a world basis but of utmost importance in the Mediterranean basin and south Asia, with a total production of 11.6 million tons from an area of 13.2 million ha and a productivity of $880 \mathrm{~kg} \mathrm{ha}^{-1}$ (FAOSTAT 2011). Global yields of chickpea have been relatively stagnant for the last two decades (Millan et al. 2006; Rao et al. 2010). Conventional and molecular breeding approaches have made success stories in creating cultivars with improved resistance to various biotic and abiotic stresses. However, adoption of such improved cultivars in developing countries is still limited because of the fluctuating environmental factors and their consequences in yield parameters in crops (Ribaut et al. 2010; Tester and Langridge 2010; Varshney et al. 2012). Hence, in the present study, it was proposed to use PGP Streptomyces as an ecofriendly and sustainable tool to enhance the plant growth and yield of chickpea. Previously, we demonstrated a set of six Streptomyces strains (CAI-13, CAI-85, CAI-93, CAI140 , CAI-155 and KAI-180) isolated from herbal vermicompost, with a potential for PGP in rice (Gopalakrishnan et al. 2014). The objectives of this investigation were to further demonstrate the six Streptomyces strains for their PGP traits in chickpea under field conditions and to confirm the colonizing ability in chickpea by scanning electron microscopy (SEM) analysis.

\section{Materials and methods}

Six strains of Streptomyces, CAI-13 (Streptomyces caviscabies; NCBI accession: KF770891), CAI-85 (Streptomyces caviscabies; NCBI accession: KF770897), CAI-93 (Streptomyces globisporus; NCBI accession: KF742498), CAI-140 (Streptomyces griseorubens; NCBI accession: KF742497), CAI-155 (Streptomyces caviscabies; NCBI accession: KF770896) and KAI-180 (Streptomyces globisporus; NCBI accession: KF742499), reported earlier by us as having potential for PGP in rice (Gopalakrishnan et al. 2014), were used in this study to prove their efficiency on plant growth promotion in chickpea.

The field trials were conducted for two cropping seasons in 2012-13 and 2013-14 at ICRISAT, Patancheru $\left(17^{\circ} 30 \mathrm{~N} ; 78^{\circ} 16 \mathrm{E}\right.$; altitude $\left.549 \mathrm{~m}\right)$ in peninsular India. The soil depth of the experimental site used was $\geq 1.2 \mathrm{~m}$ and this soil retained $200 \mathrm{~mm}$ of plant-available water in the $120 \mathrm{~cm}$ (maximum rooting depth) soil profile. The experimental field was kept fallow except for post-rainy season crop. The soil at the experimental site was Vertisols (fine montmorillonitic isohyperthermic typic pallustert) with $53 \%$ clay, $25 \%$ sand and $21 \%$ silt with an alkaline $\mathrm{pH}$ of 7.6-8.3 and an organic carbon content of 0.4-0.6\%. The mineral content of the top $0-15 \mathrm{~cm}$ soils include 24.7 , 8.6 and $298 \mathrm{mg} \mathrm{kg}^{-1}$ soil of available $\mathrm{N}, \mathrm{P}$ and $\mathrm{K}$, respectively. The fields were prepared into broad beds and furrows with $1.2 \mathrm{~m}$ wide beds flanked by $0.3-\mathrm{m}$ furrows in both seasons (2012-13 and 2013-14). Surface application and incorporation of $18 \mathrm{~kg} \mathrm{~N} \mathrm{ha}^{-1}$ and $20 \mathrm{~kg} \mathrm{P} \mathrm{ha}^{-1}$ as diammonium phosphate (DAP), were carried out 3 days before sowing in both seasons. The experiment was laid out with three replicates and subplot sizes of $4.0 \times 3 \mathrm{~m}$ rows in ridges in a randomized complete block design (RCBD) under irrigated condition.

The Streptomyces strains (CAI-13, CAI-85, CAI-93, CAI-140, CAI-155 and KAI-180) were grown individually on a starch casein broth (starch-10 g; casein- $0.3 \mathrm{~g}$; sodium chloride $-2 \mathrm{~g}$; potassium nitrate $-2 \mathrm{~g}$; dipotassium hydrogen phosphate $-2 \mathrm{~g}$; magnesium sulfate $-0.05 \mathrm{~g}$; calcium carbonate $-0.02 \mathrm{~g}$; ferrous sulfate $-0.01 \mathrm{~g}$ and; distilled water-1,000 ml) at $28{ }^{\circ} \mathrm{C}$ for $4-5$ days. Seeds of chickpea variety ICCV 2 (duration 90 days) were treated individually with a Streptomyces strain $\left(10^{8} \mathrm{CFU} \mathrm{m}{ }^{-1}\right)$ for $45 \mathrm{~min}$ and hand sown on Oct 2012 in the first year and Nov 2013 in the second year with a spacing of $30 \mathrm{~cm}$ apart, and a depth of $5 \mathrm{~cm}$ to have an estimated plant stand of at least 26 plants $\mathrm{m}^{-2}$. Streptomyces strain $(1,000 \mathrm{ml} / \mathrm{repli}$ cate; $10^{8} \mathrm{CFU} \mathrm{ml}{ }^{-1}$ ) was applied once in 15 days, from the sowing day, on the soil close to the plant until the flowering stage. Control plots contained no strains of Streptomyces. No serious plant pathogens or insect pest attacks were observed during the cropping period and the plots were kept weed-free by manual weeding. The plots were irrigated on 21 and 49 days after sowing (DAS). The chickpea crop was harvested manually on Jan 2013 in the first year and Feb 2014 in the second year. Samplings were done at 30 DAS, 60 DAS and at crop maturity. On the sampling day, plant underground and aerial parts were harvested separately with care to eliminate border effects in each plot. During both the seasons of 2012-13, 2013-14, chickpea growth performance was measured in terms of nodule number, nodule weight, root weight and shoot 
weight at 30 DAS; plant height, pod number, pod weight, leaf area, leaf weight and stem weight at 60 DAS; and stover yield, grain yield, total dry matter (TDM), 1000-seed weight, pod weight, seed number and seed weight at crop maturity. Also, at crop maturity, rhizosphere soil samples were collected from top 0 to $15 \mathrm{~cm}$ soil and analyzed for total nitrogen (Novozamsky et al. 1983), available phosphorous (Olsen and Sommers 1982), organic carbon (Nelson and Sommers 1982), microbial biomass carbon (fumigation method; Anderson and Domsch 1989) and dehydrogenase activity (triphenyl formazan production method; Casida 1977).

The colonizing capability of Streptomyces strains on the roots of chickpea was examined by scanning electron microscopy (SEM) analysis, as per the protocols of Bozzola and Russell (1998). In brief, the seeds of chickpea (variety ICCV 2) were surface-sterilized at first with $2.5 \%$ sodium hypochlorite, followed by $70 \%$ ethanol (for $5 \mathrm{~min}$ each) and rinsed thoroughly with sterilized water before being allowed to sprout in a Petri dish overnight. At the end of incubation, the sprouted seeds were soaked into test Streptomyces strains (CAI-13, CAI-85, CAI-93, CAI-140, CAI-155 and KAI-180; grown in starch casein broth separately) for 45 min before being sown in pots containing sterilized coarse sand (six seeds/8 in plastic pot). Streptomyces strains $\left(10^{8} \mathrm{CFU} \mathrm{ml}{ }^{-1} ; 5 \mathrm{ml}\right.$ per seedling), as booster doze, were applied upon germination of the seed by soil drench method. The pots were incubated at $24 \pm 2{ }^{\circ} \mathrm{C}$ in a greenhouse for 2 weeks. After that, seedlings of chickpea were removed carefully from the pots and the roots were washed in $0.1 \mathrm{M}$ phosphate buffer ( $\mathrm{pH}$ 7.2). The tips of the roots were cut into $5 \mathrm{~mm}$ long pieces and fixed in glutaraldehyde $(2.5 \%)$ in phosphate buffer for $24 \mathrm{~h}$ at $4{ }^{\circ} \mathrm{C}$. At the end of incubation, the root samples were again washed with phosphate buffer, postfixed in osmium tetroxide $(2 \%)$ for $4 \mathrm{~h}$ and dehydrated using a graded series of ethanol. The dehydrated samples were dried with critical-point liquid carbon dioxide as a transition fluid and adhered onto aluminum specimen mounted with doublestick adhesive tape. The mounted root samples were coated with gold-palladium in an automated sputter coater (JEOL JFC-1600) and examined under a scanning electron microscope (JOEL-JSM 5600) as per the standardized protocols at RUSKA lab, College of Veterinary Science, Rajendranagar, Hyderabad, India.

Data were analyzed by analysis of variance (ANOVA) and the GLM (General Linear Model) procedure in the software package SAS (SAS Inst. 2002-08, SAS V9.3) considering isolates and replication as fixed in RCBD. Isolate means were tested for significance and compared using Fisher's protected least significant difference (LSD) test.

\section{Results and discussion}

The six Streptomyces strains (CAI-13, CAI-85, CAI-93, CAI-140, CAI-155 and KAI-180) studied in this investigation were reported previously to have potential for PGP in rice (Gopalakrishnan et al. 2014). In the present investigation, these strains were evaluated for their PGP traits in chickpea under field conditions. The plots treated with Streptomyces strains showed significantly enhanced agronomic performance of all the traits measured at 30 and 60 DAS. As seen at 30 DAS in both 2012-13 and 2013-14 seasons, the Streptomyces treated plots showed significantly enhanced agronomic traits including the nodule numbers (35-83\%), nodule weight (27-64 \%), root weight (9-14) and shoot weight (32-50\%) over the un-inoculated control (Table 1). Similarly at 60 DAS, the Streptomyces strains significantly enhanced the pod number (29-95\%), pod weight (30-135\%), leaf area (32-34\%), leaf weight (25-63\%) and stem weight (23-68\%) and at crop maturity, stover yield (25-75\%), grain yield (11-26\%), total dry matter (19-32), pod weight (6-51\%), seed number (20-52) and seed weight (3-47\%) in both $2012-13$ and 2013-14 seasons over the un-inoculated control plots (Tables 1, 2). In the top $15 \mathrm{~cm}$ rhizosphere soils, at crop maturity, the Streptomyces strains treated plots significantly enhanced the microbial biomass carbon (35-55), dehydrogenase activity (27-56\%), total $\mathrm{N}(4-11)$, available P (51-106\%) and organic carbon (9-16\%) in both 2012-13 and 2013-14 seasons over the un-inoculated control plots (Table 3).

Of the six Streptomyces strains studied in the present investigation, CAI-85, CAI-93 and KAI-180 (in descending order) were found superior to CAI-155, CAI-140 and CAI-13 in terms of their effects on root and shoot development, nodule formation and crop productivity. Further, the six Streptomyces did not inhibit the growth of $\mathrm{Me}$ sorhizobium ciceri on yeast extract mannitol agar (YEMA; data not shown). Thus, it is concluded that the six Streptomyces strains are capable of enhancing agronomic and yield traits in chickpea and compatible with Rhizobium, so that co-inoculation of these two genera is possible. The effect of Streptomyces for PGP in crops including vegetables such as tomato, cereals such as wheat and rice and legumes such as beans and peas was reported widely (Tokala et al. 2002; Nassar et al. 2003; El-Tarabily 2008; Sadeghi et al. 2012; Gopalakrishnan et al. 2014). PGP bacteria with broad spectrum properties offer effective novel strategies not only for crop growth and yield but also for controlling insect pests and pathogens that attack crops. PGP bio-agents also bring forth induced systemic resistance against a broad range of pathogens and insect pests (Jetiyanon and Kloepper 2002; Ryu et al. 2007). 
Table 1 Effect of the six Streptomyces sp. on agronomic performance of chickpea under field conditions-at 30 and 60 days after sowing

\begin{tabular}{|c|c|c|c|c|c|c|c|c|c|c|c|c|c|c|c|c|c|c|}
\hline \multirow[t]{3}{*}{ Isolate } & \multicolumn{8}{|c|}{30 Days after sowing } & \multicolumn{10}{|c|}{60 Days after sowing } \\
\hline & \multicolumn{2}{|c|}{$\begin{array}{l}\text { Nodule } \\
\text { number } \\
\left.\text { plant }^{-1}\right)\end{array}$} & \multicolumn{2}{|c|}{$\begin{array}{l}\text { Nodule } \\
\text { weight } \\
\left(\mathrm{mg} \mathrm{plant}^{-1}\right)\end{array}$} & \multicolumn{2}{|c|}{$\begin{array}{l}\text { Root } \\
\text { weight } \\
\left.\text { (mg plant }^{-1}\right)\end{array}$} & \multicolumn{2}{|c|}{$\begin{array}{l}\text { Shoot weight } \\
\left(\mathrm{g} \text { plant }^{-1}\right)\end{array}$} & \multicolumn{2}{|c|}{$\begin{array}{l}\text { Plant height } \\
(\mathrm{cm})\end{array}$} & \multicolumn{2}{|c|}{$\begin{array}{l}\text { Stem weight } \\
\left(\text { g plant }^{-1}\right)\end{array}$} & \multicolumn{2}{|c|}{$\begin{array}{l}\text { Leaf area } \\
\left(\mathrm{cm}^{-2} \text { plant }^{-1}\right)\end{array}$} & \multicolumn{2}{|c|}{$\begin{array}{l}\text { Leaf weight } \\
\left(\text { g plant }^{-1}\right)\end{array}$} & \multicolumn{2}{|c|}{$\begin{array}{l}\text { Pod number } \\
\left(\text { plant }^{-1}\right)\end{array}$} \\
\hline & Y1 & $\mathrm{Y} 2$ & Y1 & $\mathrm{Y} 2$ & Y1 & Y2 & Y1 & Y2 & Y1 & $\mathrm{Y} 2$ & Y1 & $\mathrm{Y} 2$ & Y1 & $\mathrm{Y} 2$ & Y1 & Y2 & Y1 & $\mathrm{Y} 2$ \\
\hline CAI-85 & 14 & 62 & 42 & 280 & 187 & 191 & 2.02 & 2.27 & 52 & 50 & 5.24 & 4.78 & 714 & 836 & 4.52 & 4.64 & 71 & 76 \\
\hline CAI-93 & 16 & 65 & 34 & 266 & 181 & 175 & 1.84 & 1.98 & 53 & 49 & 4.85 & 3.96 & 896 & 672 & 5.71 & 3.95 & 84 & 64 \\
\hline CAI-13 & 22 & 50 & 55 & 223 & 180 & 171 & 1.61 & 1.76 & 50 & 48 & 4.59 & 3.98 & 705 & 720 & 5.28 & 3.78 & 63 & 59 \\
\hline CAI-140 & 20 & 60 & 81 & 228 & 183 & 181 & 1.49 & 1.93 & 51 & 48 & 3.90 & 4.22 & 709 & 743 & 4.82 & 3.94 & 71 & 73 \\
\hline CAI-155 & 22 & 52 & 63 & 229 & 173 & 169 & 1.56 & 1.94 & 51 & 48 & 3.40 & 3.96 & 690 & 712 & 4.43 & 4.15 & 54 & 69 \\
\hline KAI-180 & 22 & 50 & 33 & 247 & 179 & 190 & 1.51 & 1.87 & 55 & 50 & 5.63 & 4.05 & 851 & 717 & 6.99 & 4.05 & 84 & 59 \\
\hline Control & 12 & 49 & 29 & 221 & 171 & 168 & 1.35 & 1.72 & 50 & 47 & 3.36 & 3.88 & 670 & 632 & 4.29 & 3.71 & 43 & 59 \\
\hline Mean & 18 & 56 & 48 & 242 & 179 & 178 & 1.63 & 1.92 & 52 & 49 & 4.43 & 4.12 & 748 & 719 & 5.15 & 4.03 & 67 & 66 \\
\hline $\mathrm{SE} \pm$ & $1.5^{* *}$ & $0.9 * * *$ & $3.1 * * *$ & $9.4 * *$ & $2.8^{*}$ & $4.6^{* *}$ & $0.070 * * *$ & $0.066^{* *}$ & $0.3 * * *$ & $0.5 * *$ & $0.021 * * *$ & $0.178 *$ & $11.1 * * *$ & $16.2 * * *$ & $0.108 * * *$ & $0.157 *$ & $2.8 * * *$ & $2.5^{* * * *}$ \\
\hline $\operatorname{LSD}(5 \%)$ & 4.7 & 2.8 & 9.4 & 28.9 & 8.5 & 14.1 & 0.217 & 0.204 & 1.0 & 1.6 & 0.065 & 0.549 & 34.1 & 49.9 & 0.333 & 0.484 & 8.5 & 7.8 \\
\hline $\mathrm{CV} \%$ & 14 & 3 & 11 & 7 & 3 & 4 & 8 & 6 & 1 & 2 & 1 & 8 & 3 & 4 & 4 & 8 & 7 & 7 \\
\hline
\end{tabular}

Y1 year 1 (2012-13), Y2 year 2 (2013-14), SE standard error, LSD least significant differences, $C V$ coefficients of variation

* Statistically significant at 0.05 ; * Statistically significant at 0.05 ; *** Statistically significant at 0.001

Table 2 Effect of the six Streptomyces sp. on agronomic performance and yield potential of chickpea under field conditions-at harvest

\begin{tabular}{|c|c|c|c|c|c|c|c|c|c|c|c|c|c|c|}
\hline \multirow[t]{2}{*}{ Isolates } & \multicolumn{2}{|c|}{$\begin{array}{l}\text { Stover yield } \\
\left(\mathrm{t} \mathrm{ha}^{-1}\right)\end{array}$} & \multicolumn{2}{|c|}{$\begin{array}{l}\text { Grain yield } \\
\left(\mathrm{t} \mathrm{ha}^{-1}\right)\end{array}$} & \multicolumn{2}{|c|}{$\begin{array}{l}\text { Total dry } \\
\text { matter }\left(\mathrm{t} \mathrm{ha}^{-1}\right)\end{array}$} & \multicolumn{2}{|c|}{$\begin{array}{l}1000 \text { seed } \\
\text { (weight g) }\end{array}$} & \multicolumn{2}{|c|}{$\begin{array}{l}\text { Pod weight } \\
\left(\mathrm{g} \mathrm{plant}^{-1}\right)\end{array}$} & \multicolumn{2}{|c|}{$\begin{array}{l}\text { Seed number } \\
\left(\text { plant }^{-1}\right)\end{array}$} & \multicolumn{2}{|c|}{$\begin{array}{l}\text { Seed weight } \\
(\mathrm{g} \text { plant }\end{array}$} \\
\hline & $\mathrm{Y} 1$ & Y2 & Y1 & Y2 & Y1 & $\mathrm{Y} 2$ & Y1 & Y2 & Y1 & Y2 & Y1 & Y2 & Y1 & $\mathrm{Y} 2$ \\
\hline CAI-85 & 1.64 & 1.81 & 1.86 & 2.10 & 3.50 & 3.91 & 222 & 196 & 18.3 & 22.7 & 56 & 84 & 15.3 & 16.4 \\
\hline CAI-93 & 1.30 & 1.76 & 1.76 & 1.81 & 3.06 & 3.57 & 221 & 198 & 18.1 & 19.5 & 58 & 73 & 15.3 & 15.7 \\
\hline CAI-13 & 1.94 & 1.80 & 1.76 & 1.79 & 3.69 & 3.58 & 222 & 198 & 18.4 & 21.3 & 65 & 80 & 15.3 & 16.3 \\
\hline CAI-140 & 1.48 & 1.80 & 1.80 & 2.06 & 3.24 & 3.86 & 223 & 205 & 17.7 & 21.3 & 57 & 76 & 15.5 & 15.6 \\
\hline CAI-155 & 1.58 & 1.74 & 1.75 & 1.81 & 3.33 & 3.55 & 223 & 197 & 17.9 & 22.2 & 58 & 87 & 15.5 & 17.1 \\
\hline KAI-180 & 1.40 & 2.10 & 1.76 & 1.87 & 3.16 & 3.97 & 223 & 196 & 17.6 & 25.7 & 61 & 100 & 15.5 & 19.6 \\
\hline Control & 1.11 & 1.68 & 1.68 & 1.67 & 2.79 & 3.34 & 220 & 195 & 17.4 & 17.0 & 54 & 66 & 15.0 & 13.3 \\
\hline Mean & 1.49 & 1.81 & 1.77 & 1.87 & 3.26 & 3.68 & 222 & 198 & 17.9 & 21.4 & 58 & 81 & 15.4 & 16.3 \\
\hline $\mathrm{SE} \pm$ & $0.049 * * *$ & $0.068^{*}$ & $0.011 * * *$ & $0.068 * *$ & $0.047 * * *$ & $0.092 * *$ & $0.4 * * *$ & $1.2 * * *$ & $0.18 * *$ & $1.18^{* *}$ & $1.2 * *$ & $3.2 * * *$ & $0.08 * *$ & $0.68 * *$ \\
\hline LSD (5\%) & 0.200 & 0.206 & 0.033 & 0.210 & 0.146 & 0.284 & 1.2 & 3.6 & 0.57 & 3.66 & 3.7 & 9.9 & 0.25 & 2.10 \\
\hline CV \% & 6 & 6 & 1 & 6 & 3 & 4 & 1 & 1 & 2 & 10 & 4 & 7 & 1 & 7 \\
\hline
\end{tabular}

Y1 year 1 (2012-13), Y2 year 2 (2013-14), SE standard error, $L S D$ least significant differences, $C V$ coefficients of variation

* Statistically significant at 0.05 ; ** Statistically significant at 0.05 ; *** Statistically significant at 0.001

SEM analysis of chickpea roots showed a remarkable degree of colonization by all the six strains of Streptomyces. Roots from Streptomyces inoculated plants exhibited significant surface colonization while those from uninoculated plants did not. Further, the sporulation of Streptomyces strains on the surface cell layer of chickpea roots was clearly evident for all six strains. The hyphae of Streptomyces strains were also found to penetrate the surface cell layer of chickpea roots (Fig. 1). Colonization by
PGP bacteria at the right time and place is a pre-requisite for enhanced PGP activity. Host-bacteria interaction is important for colonization which involves sufficient population of bacteria, rhizosphere competence of the bacteria and root colonizing and PGP ability of the bacteria (Lugtenberg and Dekkers 1999). In the present investigation, SEM analysis demonstrated colonization of Streptomyces strains on the roots of chickpea. Therefore, the SEM analysis, in addition to the data for grain and stover yield, 
Table 3 Effect of the six Streptomyces sp. on rhizosphere soil microbial biomass carbon, dehydrogenase, total N, available P and organic carbon activities of chickpea under field conditions—at harvest

\begin{tabular}{|c|c|c|c|c|c|c|c|c|c|c|}
\hline \multirow[t]{2}{*}{ Isolates } & \multicolumn{2}{|c|}{$\begin{array}{l}\text { Microbial biomass } \\
\text { carbon }\left(\mu \mathrm{g} \mathrm{g}^{-1} \text { soil }\right)\end{array}$} & \multicolumn{2}{|c|}{$\begin{array}{l}\text { Dehydrogenase activity } \\
\left(\mu \mathrm{g} \text { TPF } \mathrm{g}^{-1} \text { soil } 24 \mathrm{~h}^{-1}\right)\end{array}$} & \multicolumn{2}{|c|}{$\begin{array}{l}\text { Total N } \\
(\mathrm{ppm})\end{array}$} & \multicolumn{2}{|c|}{$\begin{array}{l}\text { Available P } \\
(\mathrm{ppm})\end{array}$} & \multicolumn{2}{|c|}{$\begin{array}{l}\text { Organic } \\
\text { carbon }(\%)\end{array}$} \\
\hline & Y1 & Y2 & Y1 & Y2 & Y1 & Y2 & Y1 & Y2 & Y1 & Y2 \\
\hline CAI-85 & 1,042 & 576 & 58.0 & 58.7 & 701 & 738 & 11.0 & 7.5 & 0.51 & 0.56 \\
\hline CAI-93 & 1,183 & 856 & 59.9 & 62.2 & 643 & 751 & 10.6 & 7.6 & 0.49 & 0.56 \\
\hline CAI-13 & 1,128 & 774 & 60.4 & 63.0 & 683 & 739 & 11.3 & 9.5 & 0.50 & 0.56 \\
\hline CAI-140 & 958 & 630 & 61.6 & 76.0 & 683 & 746 & 12.2 & 10.4 & 0.49 & 0.56 \\
\hline CAI-155 & 987 & 574 & 70.3 & 60.0 & 704 & 762 & 20.8 & 7.8 & 0.48 & 0.64 \\
\hline KAI-180 & 1097 & 822 & 63.1 & 86.7 & 637 & 755 & 19.3 & 8.8 & 0.49 & 0.60 \\
\hline Control & 877 & 551 & 55.4 & 55.7 & 632 & 735 & 10.1 & 6.9 & 0.47 & 0.55 \\
\hline Mean & 1039 & 683 & 61.2 & 66.1 & 669 & 746 & 13.6 & 8.3 & 0.49 & 0.57 \\
\hline $\mathrm{SE} \pm$ & $20.7 * * *$ & $24.8^{* * *}$ & $2.13 *$ & $3.19 * *$ & $11.8^{*}$ & $4.8^{*}$ & $0.18 * * *$ & $0.53 *$ & $0.004 * *$ & $0.008 * *$ \\
\hline $\operatorname{LSD}(5 \%)$ & 71.7 & 84.8 & 7.38 & 11.04 & 41.0 & 16.5 & 0.62 & 1.83 & 0.013 & 0.026 \\
\hline CV \% & 3 & 5 & 5 & 7 & 3 & 1 & 2 & 9 & 1 & 2 \\
\hline
\end{tabular}

$Y 1$ year 1 (2012-13), Y2 year 2 (2013-14), SE standard error, $L S D$ least significant differences, $C V$ coefficients of variation

* Statistically significant at 0.05 ; ** Statistically significant at 0.05 ; *** Statistically significant at 0.001

root and other agronomical traits, and the mineral nutrients and biological activities of the rhizosphere soil strongly suggest that the six Streptomyces strains had multiplied and colonized on the chickpea roots.

The mechanism by which the six Streptomyces strains consistently enhanced yield and agronomical traits on rice (from our previous study) and chickpea (from this study) could be attributed to their ability to produce siderophores, indole acetic acid (IAA) and $\beta$-1,3-glucanase activities (Gopalakrishnan et al. 2014). Bacteria are reported to have the ability to produce low-molecular weight siderophores that are capable of sequestering $\mathrm{Fe}^{3+}$ and to help plants to have their iron requirement. Siderophores act as solubilizing agents of iron from minerals under conditions of iron limitation (Indiragandhi et al. 2008). Siderophores are reported to form stable complexes with heavy metals such as $\mathrm{Al}, \mathrm{Cd}, \mathrm{Cu}, \mathrm{Ga}, \mathrm{In}, \mathrm{Np}, \mathrm{Pb}, \mathrm{U}$ and $\mathrm{Zn}$ and increase the soluble metal concentration (Rajkumar et al. 2010). Therefore, siderophores help to alleviate the stresses imposed on plants by heavy metals in soils. IAA is the plant hormone that accelerates plant growth by enhancing shoot/root growth and seedling vigour. IAA synthesizing bacteria are known to stimulate seed germination, initiate root formation and increase root length and surface area thereby providing the host plant greater access to water and soil nutrients (Ahemad and Kibret 2014). The cell wall of plant pathogens, such as Fusarium oxysporum (causes wilt in many crops), contain layers of $\beta-1,3$-glucan and lysis of $\beta$-1,3-glucan layers by $\beta$-1,3-glucanase-producing bacteria leads to the leakage of cell contents and the collapse of the pathogenic fungi (Singh et al. 1999). Furthermore, qRTPCR validation of IAA genes revealed that gene IAA showed higher up regulation in the CAI- 85 followed by CAI-93 while gene siderophore was highly up-regulated in CAI-155 followed by CAI-85 and CAI-93 and this results confirmed the results of in vitro PGP attributes of the six Streptomyces strains (from our previous study; Gopalakrishnan et al. 2014).Hence, it is concluded that the Streptomyces strains used in this investigation apparently contained a broad range of PGP traits which can be exploited for PGP in cereal-legum cropping system.

It is concluded that the six Streptomyces strains (CAI13, CAI-85, CAI-93, CAI-140, CAI-155 and KAI-180) studied in this investigation were apparently well adapted not only in rice rhizosphere, as reported earlier, but also in the chickpea rhizosphere. Among the six Streptomyces strains studied, CAI-85, CAI-93 and KAI-180 were found to be the best performers than other isolates in terms of agronomic performance and crop productivity. Therefore, these three strains are potential candidates for the discovery of novel secondary metabolites and their usefulness in integrated nutrient management programs that can help in furthering the use of eco-friendly bio-fertilizers. Further studies are needed to understand the importance of these six PGP Streptomyces in the rhizosphere and their potential use in the environment. Also, there is a need to do additional comprehensive research to exploit the potential of these PGP Streptomyces under different field conditions 
Fig. 1 Scanning electron microscopy photographs of the six Streptomyces sp. showing colonization on the roots of chickpea. Representative SEM images of control and treated chickpea roots. a Normal surface of chickpea roots without any microbial treatment, $\mathbf{b}-\mathbf{g}$ chickpea roots colonized by PGP Streptomyces strains CAI-13, CAI-85, CAI93, CAI-140, CAI-155 and KAI-180 respectively
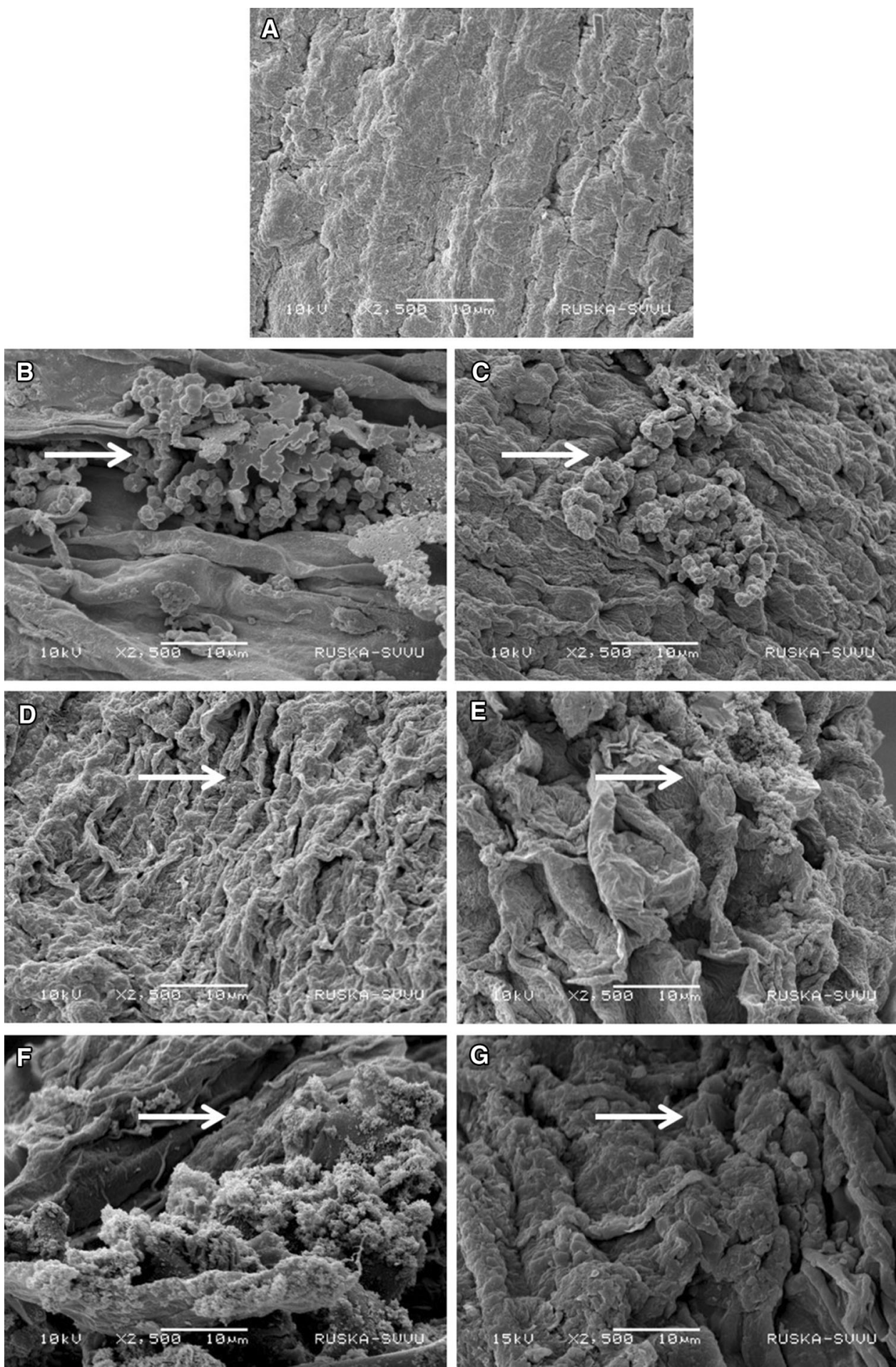

(multi-location trials), commercialization and improve sustainability in agricultural production.

Acknowledgments This work has been undertaken as part of the CGIAR Research Program on Grain Legumes. ICRISAT is a member of CGIAR Consortium. We thank Dr. M. Lakshman, Associate Professor, Ruska Lab, College of Veterinary Science, Rajendranagar,
Hyderabad, for SEM analysis and all the staff of the biocontrol unit of ICRISAT including M/s PVS. Prasad, P. Manohar, B. Nagappa, D. Barath, A. Jabbar and S. Rohini for their significant contributions in the laboratory and field studies.

Conflict of interest All the authors declare that they have no financial/commercial conflicts of interest. 
Open Access This article is distributed under the terms of the Creative Commons Attribution License which permits any use, distribution, and reproduction in any medium, provided the original author(s) and the source are credited.

\section{References}

Ahemad M, Kibret M (2014) Mechanisms and applications of plant growth promoting rhizobacteria: current perspective. J King Saud Univ 26:1-20

Aldesuquy HS, Mansour FA, Abo-Hamed SA (1998) Effect of the culture filtrates of Streptomyces on growth and productivity of wheat plants. Folia Microbiol 43:465-470

Anderson TH, Domsch KH (1989) Ratios of microbial biomass carbon to total organic carbon in arable soils. Soil Biol Biochem 21:471-479

Bozzola JJ, Russell LD (1998) Specimen preparation for scanning electron microscopy, 3rd chap. In: Electron microscopy principals and techniques for biologists, 2nd edn. Jones and Barlett publishers, Sudbury, Massachusetts, pp 19-24, 54-55, 63-67

Casida LE (1977) Microbial metabolic activity in soil as measured by dehydrogenase determinations. Appl Environ Microbiol 34:630-636

Cheng Z, Park E, Glick BR (2007) 1-Aminocyclopropane-1-carboxylate deaminase from Pseudomonas putida UW4 facilitates the growth of canola in the presence of salt. Can J Microbiol 53:912-918

El-Tarabily KA (2008) Promotion of tomato (Lycopersicon esculentum Mill.) plant growth by rhizosphere competent L-aminocyclopropane-L-carboxylic acid deaminase-producing Streptomycete actinomycetes. Plant Soil 308:161-174

Esitken A, Karlidag H, Ercisli S, Sahin F (2002) Effects of foliar application of Bacillus substilis Osu-142 on the yield, growth and control of shot-hole disease (Coryneum blight) of apricot. Gartenbauwissenschaft 67:139-142

FAOSTAT (2011) Statistical database 2011. Available at http:// faostat.fao.org/site/339/default.aspx

Glick BR (2010) Using soil bacteria to facilitate phytoremediation. Biotechnol Adv 28:367-374

Gopalakrishnan S, Kiran BK, Humayun P, Vidya MS, Deepthi K, Rupela O (2011a) Biocontrol of charcoal-rot of sorghum by actinomycetes isolated from herbal vermicompost. Afr $\mathrm{J}$ Biotechnol 10:18142-18152

Gopalakrishnan S, Pande S, Sharma M, Humayun P, Kiran BK, Sandeep D, Vidya MS, Deepthi K, Rupela O (2011b) Evaluation of actinomycete isolates obtained from herbal vermicompost for biological control of Fusarium wilt of chickpea. Crop Prot 30:1070-1078

Gopalakrishnan S, Vadlamudi S, Apparla S, Bandikinda P, Vijayabharathi R, Bhimineni RK, Rupela O (2013) Evaluation of Streptomyces $\mathrm{sp}$. for their plant growth-promotion traits in rice. Can J Microbiol 59:534-539

Gopalakrishnan S, Vadlamudi S, Bandikinda P, Sathya A, Vijayabharathi R, Rupela O, Kudapa B, Katta K, Varshney RK (2014) Evaluation of Streptomyces strains isolated from herbal vermicompost for their plant growth-promotion traits in rice. Microbiol Res 169:40-48

Hao D, Gao P, Liu P, Zhao J, Wang Y, Yang W, Lu Y, Shi T, Zhang $\mathrm{X}$ (2011) AC3-33, a novel secretory protein, inhibits Elk1 transcriptional activity via ERK pathway. Mol Biol Rep 38:1375-1382

Indiragandhi P, Anandham R, Madhaiyan M, Sa TM (2008) Characterization of plant growth-promoting traits of bacteria isolated from larval guts of diamondback moth Plutella xylostella (Lepidoptera; Plutellidae). Curr Microbiol 56:327-333

Jetiyanon K, Kloepper JW (2002) Mixtures of plant growth promoting rhizobacteria for induction of systemic resistance against multiple plant diseases. Biol Control 24:285-291

Lugtenberg BJJ, Dekkers LC (1999) What makes Pseudomonas bacteria rhizosphere competent? Environ Microbiol 1:9-13

Macagnan D, Romeiro RDA, Pomella AMV, deSouza JT (2008) Production of lytic enzymes and siderophores, and inhibition of germination of basidiospores of Moniliophthora (ex Crinipellis) perniciosa by phylloplane actinomycetes. Biol Control 47:309-314

Mahadevan B, Crawford DL (1997) Properties of the chitinase of the antifungal biocontrol agent Streptomyces lydicus WYEC108. Enzyme Microb Techol 20:489-493

Millan T, Clarke HJ, Siddique KH, Buhariwalla HK, Gaur PM, Kumar J, Gil J, Kahl G, Winter P (2006) Chickpea molecular breeding: new tools and concepts. Euphytica 147:81-103

Nassar AH, El-Tarabily KA, Sivasithamparam K (2003) Growth promotion of bean (Phaseolus vulgaris L.) by a polyamine producing isolate of Streptomyces griseoluteus. Plant Growth Regul 40:97-106

Nelson DW, Sommers LE (1982) Total organic carbon and organic matter'. In: Page AL, Miller RH, Keeney DR (eds) Methods of soil analysis, part 3, chemical and microbiological properties. SSSA, Madison, pp 539-579

Novozamsky I, Houba VJG, Van ECKR, vanVark W (1983) A novel digestion technique for multiple element analysis. Commun Soil Sci Plant Anal 14:239-249

Olsen SR Sommers LE (1982) Phosphorus. In: Page AL (ed) Methods of soil analysis, Agron No 9, part 2, chemical and microbial properties, 2nd edn, Am Soc Agron, Madison, pp 403-430

Panhwar QA, Othman R, Rahman ZA, Meon S, Ismail MR (2012) Isolation and characterization of phosphate-solubilizing bacteria from aerobic rice. Afr J Biotechnol 11:2711-2719

Perner H, Schwarz D, George E (2006) Effect of mycorrhizal inoculation and compost supply on growth and nutrient uptake of young leek plants grown on peat-based substrates. Hort Sci 41:628-632

Postma J, Montanari M, Van den Boogert PHJF (2003) Microbial enrichment to enhance disease suppressive activity of compost. Eur J Soil Biol 39:157-163

Rajkumar M, Ae N, Prasad MNV, Freitas H (2010) Potential of siderophore-producing bacteria for improving heavy metal phytoextraction. Trends Biotechnol 28:142-149

Rao PP, Birthal PS, Bhagavatula S, Bantilan MCS (2010) Chickpea and pigeonpea-economies in Asia: facts, trends and outlook. International Crops Research Institute for the Semi-Arid Tropics, Hyderabad

Ribaut JM, de Vicente MC, Delannay X (2010) Molecular breeding in developing countries: challenges and perspectives. Curr Opin Plant Biol 13:213-218

Richardson AE, Barea JM, Mcneill AM, Combaret CP (2009) Acquisition of phosphorus and nitrogen in the rhizosphere and plant growth promotion by microorganisms. Plant Soil 321:305-339

Ryu CM, Murphy CF, Reddy MS, Kloepper JW (2007) A two strain mixture of rhizobacteria elicits induction of systemic resistance against Pseudomonas syringae and Cucumber mosaic virus coupled to promotion of plant growth on Arabidopsis thaliana. J Microbiol Biotechnol 17:280-286

Sadeghi A, Karimi E, Dahazi PA, Javid MG, Dalvand Y, Askari H (2012) Plant growth promoting activity of an auxin and siderophore producing isolate of Streptomyces under saline soil condition. World J Microbiol Biotechnol 28:1503-1509

Shaukat K, Affrasayab S, Hasnain S (2006) Growth responses of Triticum aestivum to plant growth promoting Rhizobacteria used as a biofertilizer. Res J Microbiol 1:330-338 
Singh PP, Shin YC, Park CS, Chung YR (1999) Biological control of Fusarium wilt of cucumber by chitinolytic bacteria. Phytopathology 89:92-99

Soares RA, Roesch LPW, Zanatta G, Camargo FAD, Passaglia LMP (2006) Occurrence and distribution of nitrogen fixing bacterial community associated with oat (Avena sativa) assessed by molecular and microbiological techniques. Appl Soil Ecol 33:221-234

Tester M, Langridge P (2010) Breeding technologies to increase crop production in a changing world. Science $327: 818-822$
Tokala RK, Strap JL, Jung CM, Crawford DL, Salove MH, Deobald LA, Bailey JF, Morra MJ (2002) Novel plant-microbe rhizosphere interaction involving Streptomyces lydicus WYEC108 and the pea plant (Pisum sativum). Appl Environ Microbiol 68:2161-2171

Trejo-Estrada SR, Paszczynski A, Crawford DL (1998) Antibiotics and enzymes produced by the biocontrol agent Streptomyces violaceusniger YCED-9. J Ind Microbiol Biot 21:81-90

Varshney RK, Ribaut J, Buckler ES, Tuberosa R, Rafalski JA, Langridge P (2012) Can genomics boost productivity of orphan crops? Nat Biotechnol 30:1172-1176 